\title{
Penyuluhan Manajemen Beternak Itik untuk Meningkatkan Ketersediaan Bahan Baku Telur Asin
}

\author{
Moh. Hasil Tamzil*, Budi Indarsih, I Nyoman Sukartha Jaya, Ni Ketut Dewi Haryani, Asnawi \\ Laboratorium Ternak Unggas Fakultas Peternakan Universitas Mataram. \\ Jalan Majapahit no. 62 Mataram, Lombok Nusa Tenggara Barat. Indonesia. 83125
}

\author{
Article history \\ Received: 28-08-2019 \\ Revised: 02-10-2019 \\ Accepted: 07-07-2020 \\ *Corresponding Author: \\ Moh. Hasil Tamzil \\ Laboratorium Ternak Unggas \\ Fakultas Peternakan \\ Universitas Mataram. \\ Jalan Majapahit no. 62 \\ Mataram, Lombok Nusa \\ Tenggara Barat. Indonesia; \\ Email: \\ emhatamsil@yahoo.com
}

\begin{abstract}
The extension activity aimed to improve the duck farmer skills in duck farming system in Candi Manik village, Sekotong Sub-District, West Lombok District. The activity was successfully conducted due to collaboration among several parties, including village officials, KKN student of University of Mataram, and lecturers of Faculty of Animal Science University of Mataram. The activity was carried out using talk and discussion methods. All of the invited participants attended the activity until the end. The whole activity ran smoothly and in orderly manner. Materials presented during the activity were needed by the participants, especially the duck farmers. Thus, it can be concluded that, the extension activity was a success as it met the planned targets and objectives. Materials given were: breeding, feed and feeding, menegement of rearing sytem, disease and disease contole, and post-harvest handling management. All of the participants attended the extension activity until the end. The whole extension activities consisting of discussions, questions and answers sessions took place in an orderly manner. The discussed extension topics were material needed by participants, especially for duck farmers. Thus it can be concluded that the material provided can improve duck farming skills of the participants in order to increase egg production as salted egg raw materials.
\end{abstract}

Keywords: extension; duck; salted eggs

Abtrak: Kegiatan penyuluhan bertujuan untuk meningkatkan keterampilan sistem beternak itik bagi penggiat peternakan itik di desa Cendi Manik, kecamatan Sekotong, kabupaten Lombok Barat. Kegiatan penyuluhan terselenggara berkat kerjasama berbagai pihak, yaitu aparat desa, Mahasiswa Kuliah Kerja Nyata Universitas Mataram, serta staf pengajar pada Laboratorium Ternak Unggas, Fakultas Peternakan Universitas Mataram. Kegiatan penyuluhan dilaksanakan dengan metode ceramah dan diskusi. Materi yang diberikan adalah: pembibitan, pakan dan pemberian pakan, sistem pemeliharaan, Penyakit dan pencegahan penyakit, serta pengelolaan pasca panen. Semua peserta penyuluhan mengikuti semua rangkaian penyuluhan dengan baik. Semua rangkaian penyuluhan, diskusi dan tanya jawab berlangsung tertib dan teratur. Materi penyuluhan dipandang sebagai materi yang sangat dibutuhkan oleh peserta terutama bagi penggiat peternakan itik. Dengan demikian dapat disimpulkan bahwa materi penyuluhan yang diberikan dapat meningkatkan keterampilan beternak itik bagi peserta dalam upaya untuk meningkatkan produksi telur segar bahan baku telur asin.

Kata Kunci: penyuluhan; cindra mata; itik; telur asin 


\section{PENDAHULUAN}

Pulau Lombok sebagai destinasi wisata halal, memiliki kuliner khas yaitu telur asin dengan cita rasa yang unik dan dapat digunakan sebagai oleh-oleh atau cindra mata oleh setiap wisatawan yang datang ke pulau Lombok. Permasalahan utama dalam industri telur asin adalah keterbatasan pengadaan bahan baku (telur itik segar). Peternakan itik rakyat sebagai sumber baahan baku, menerapkan menejemen sederhana dan dengan tingkat pemilikan yang rendah, sedangkan pemilikan dengan skala besar dihadapkan dengan harga pakan komersial dan variasi genetik ternak itik yang dipelihara sangat tingginya (Tamzil, 2017). Akibat biaya pakan yang dikeluarkan tidak sebanding dengan produksi telur yang dihasilkan, berdampak pada menurunnya minat pelaku sektor produksi telur itik, berkurangnya persediaan telur itik segar, telur asin terbatas dengan harga yang mahal. Oleh sebab itu peternak itik perlu diberi tambahan pengetahuan untuk menggerakkan aktivitas di sektor hulu, sehinggga pengadaan telur segar sebagai bahan baku telur asin tetap tersedia.

\section{METODE}

1. Metode Pelaksanaan: Metode yang dipergunakan dalam kegiatan penyuluhan ini adalah metode ceramah, diskusi dan tanya jawab.

2. Tempat dan Waktu: Kegiatan penyuluhan ini dilakukan pada hari Sabtu tanggal 2 Februari 2019, mulai dari jam 9.00 waktu Indonesia Bagian Tengah sampai selesai, di Kantor Desa Cendi Manik Kecamatan Sekotong Kabupaten Lombok Barat.

3. Variabel: Variabel yang dipergunakan sebagai tolok ukur keberhasilan penyluhan ini adalah 1) tingkat keseriusan peserta mengikuti semua rangkaian acara, 2) tingkat kegairahan waktu acara diskusi dan tanya jawab.

4. Mitra Pelaksana: Acara penyuluhan ini terselenggara atas kerjasama dari 1). Aparat Desa Cendi Manik, kecamatan Sekotong, Lombok Barat, 2). Mahasiswa Kuliah Kerja Nyata (KKN) Universitas Mataram dan 3). Staf Pengajar pada Laboratorium Ternak Unggas, Fakultas Peternakan Universitas Mataram.

5. Peserta: Peserta aktif dari kegiatan penyuluhan ini terdiri dari beberapa komponen, yaitu petani peternak (peternak itik), aparat desa, dan Mahasiswa KKN Universitas Mataram.

6. Mekanisme Persiapan Acara: Terbentuknya kata sepakat untuk pelaksanaan acara penyuluhan ini, pada mulanya diinisiasi oleh Mahasiswa KKN Universitas Mataram. Hasil surve pendahuluan mendapatkan adanya peternak itik yang mempunyai kasus husus dan meminta pola pemecahan. Kasus lapangan ini diangkat sebagai salah satu program kerja, dan meminta bantuan ke Fakultas Peternakan Universitas Mataram sebagai pelaksana. Setelah melalui berbagai proses, maka disepakatilah untuk dilakukan acara penyuluhan untuk memberikan jalan keluar terhadap permasalahan yang dihadapi peternakan.

\section{HASIL DAN PEMBAHASAN}

Materi penyuluhan yang disampaikan terdiri dari: 1) Pembibitan. Pada bahasan ini disampaikan bagaimana memilih telur tetas, proses penetasan, dan metode memilih anak itik ( $\mathrm{DOD}=$ day old duck) serta induk yang produktif. 2). Pakan, Bagian ini berisi bahan-bahan pakan itik, kebutuhan nutrisi ternak itik, nilai nutrisi pakan dan pola pemberian pakan. Pada materi ini 
disampaikan bahwa supaya ternak itik dapat tumbuh dan berproduksi (bertelur) dengan baik diperlukan adanya asupan gizi yang lengkap (energy, protein, asam amino, vitamin dan mineral). Bahan-bahan pakan alternatif yang dapat dipergunakan sebagai pakan itik tanpa mengganggu produksi dan kesehatan ternak. 3). Sistem Pemeliharaan. Pola pemeliharaan ternak itik terdiri dari 3 sistem, yaitu: sistem intensif, semi intensif dan ekstensif (Tamzil, 2017). Sistem intensif adalah system pemeliharaan secara terkurung. Penggunaan sistem pemeliharaan intensif cenderung lebih mahal, karena semua kebutuhan ternak seperti pakan, air minum dan obat-obatan harus disediakan oleh peternak, namun sistem ini usaha peternakan itik dapat dikembangkan dalam sekala besar. Pemeliharaan secara semi intensif adalah pemeliharaan ternak itik dengan cara pada siang hari digembalakan atau dibiarkan berkeliaran pada tempat-tempat yang memungkinkan banyak tersedia bahan pakan, seperti di daerah persawahan (sumber gabah yang tercecer, siput, cacing dan lain sebagainya), sedangkan pada malam hari dimasukkan ke dalam kandang. Sistem ini cukup efektif diterapkan pada peternakan skala kecil, namun tidak bisa diterapkan pada peternakan skala besar. Sistem pemeliharaan secara ekstensif adalah sistem pemeliharaan secara gembala. Sistem ini ternak itik digembalakan berkeliling dari suatu tempat ke tempat lain yang banyak tersedia bahan makanan. Sistem ini merupakan metode pemeliharaan ternak itik yang paling tradisional, karena berpindah dari satu tempat ke tempat yang lain. 4). Pengenalan penyakit dan upaya penanggulangannnya. Jenis-jenis penyakit yang diperkenalkan pada acara penyuluhan ini adalah penyakit-penyakit itik yang disebabkan oleh Protozoa, Jamur, bakteri dan virus (Hesti, 2018). Diantara penyakit-penyakit tersebut ada yang bersifat zoonosis, seperti halnya penyakit Flu Burung (WHO, 1959). 5). Pengelolaan pasca panen. Materi ini difokuskan pada metode pengawetan telur menggunakan metode pengasinan (telur asin). Setelah acara tatap muka selesai, dilanjutkan dengan peninjauan langsung ke lokasi usaha (kandang) salah seorang peserta.

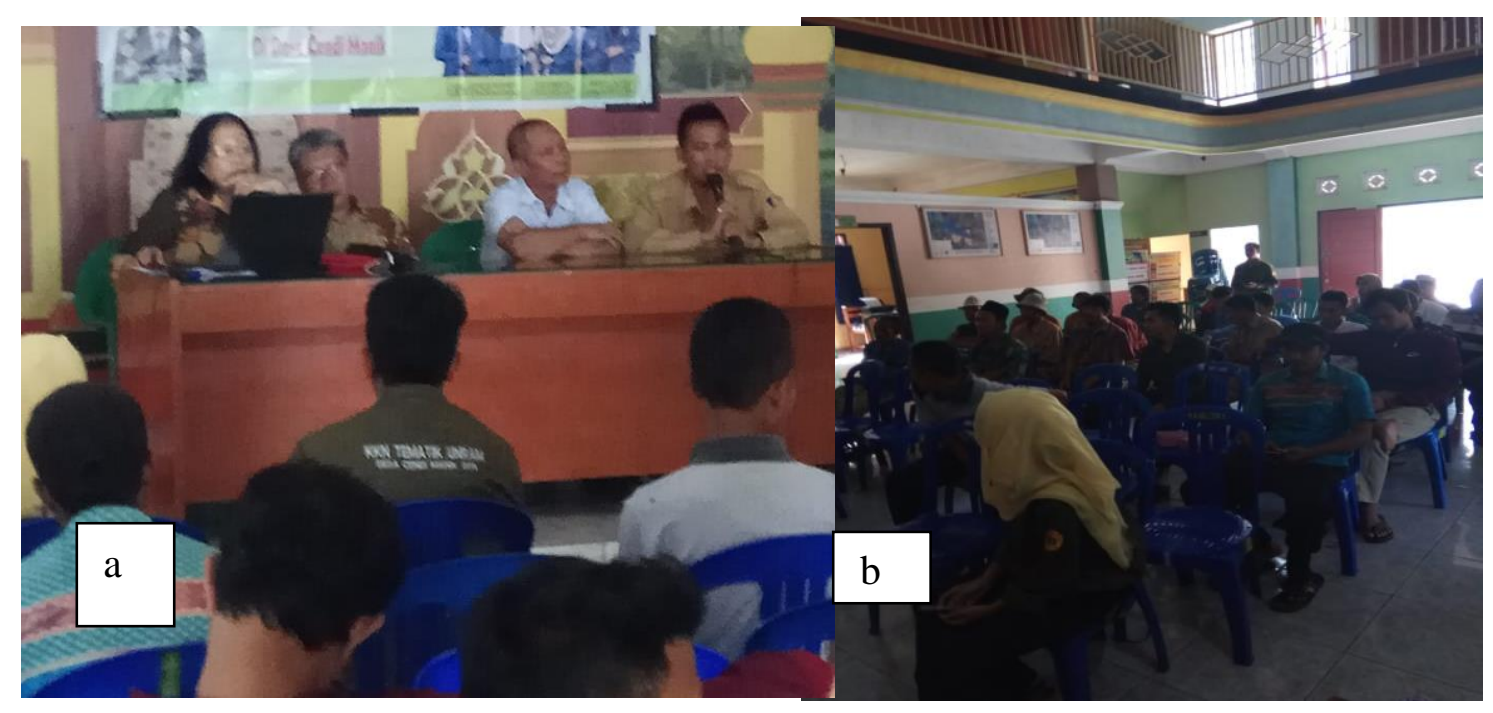

Gambar 1a. Penyampaian Materi Penyuluhan, Gambar b. Suasana Peserta Penyuluhan

Masalah ternak itik yang menghasilkan produksi telur rendah, tidak mampu mengimbangi biaya pakan komersial yang mahal, disebabkan oleh banyak faktor seperti rendahnya kualitas bibit yang dipelihara, umur ternak itik yang tidak seragam dan rendahnya nilai nutrisi pakan yang diberikan (Tamzil, 2017). Produksi telur itik yang digembalakan hanya mencapai 26,9 - 41,3\%, sedangkan bila 
dipelihara secara intensif produksi telur dapat mencapai angka 55,6\% (Stioko, 1990), bahkan dapat mencapai angka 69,4\% selama 1 tahun (Ketaren dan Prasetyo, 2000, Ketaren 2003). Untuk dapat mengurangi biaya produksi oleh peternak di lokasi penyuluhan disarankan untuk menggunakan pakan alternative berbasis lokal.

Letak geografis desa Cendi Manik lokasi penyuluhan berada di pinggir pantai dengan pemanfaatan lahan terpokus pada lahan sawah yang baik untuk tumbuh kembangnya keong mas, sedangkan lahan tambak berpotensi sebagai penghasil limbah kepala udang dan biota-biota pantai lainnya seperti kepiting. Biota-biota tersebut merupakan sumber protein dan mineral yang sangat baik untuk pakan ternak itik petelur (Purnamaningsih, 2010).

Persoalan lain yang muncul dalam diskusi adalah masalah rendahnya umur simpan dedak halus. Ketersediaan sedak halus pada musim panen melimpah, namun memiliki daya simpan rendah, tetapi pada musim kemarau pengadaan sangat terbatas. Rendahnya daya simpan dedak halus ini disebabkan karena ketidakstabilan dedak padi selama penyimpanan. Ketidakstabilan ini disebabkan karena aktivitas enzim yang menyebabkan kerusakan atau ketengikan oksidatif pada komponen minyak yang ada dalam dedak padi (Amrullah, 20020). Suatu teknologi penyimpanan dedak padi dengan cara fermentasi anaerob dapat memperpanjang waktu simpan dan menurunkan kandungan asam fitat sehingga penggunaannya dapat lebih maksimal dalam ransum (Balitbangtan, 2019). Fermentasi merupakan proses pemecahan senyawa organik menjadi senyawa sederhana dengan melibatkan mikroorganisme (Wibawa et al. 2015). Tujuannya adalah untuk meningkatkan kandungan nutrisi dan menurunkan zat anti nutrisi suatu produk sehingga menjadi lebih baik (Wahyuni, 2003). Solusi alternative yang dapat diaplikasikan oleh peternak adalah menggunakan teknologi kearipan local "sangrai", yaitu dengan melakukan sangrai atau menggoreng dedak tanpa minyak sebelum penyimpanan.

Kegiatan penyuluhan ini dapat memberikan tambahan keterampilan dalam sistem budidaya ternak itik. Beberapa hal yang berperan sebagai kekuatan untuk mencapai tujuan tersebut antara lain adalah: 1). Peserta pelatihan sudah banyak yang menggeluti pekerjaan beternak itik dalam kurun waktu yang cukup lama, 2). Materi yang disampaikan sangat sesuai dengan kebutuhan, 3). Umur peserta rata-rata umur produktif, yaitu umur yang dengan tingkat keingin-tauan dan keberanian berspekulasi cukup tinggi. Meskipun demikian ada beberapa factor yang menjadi kelemahan, yaitu: 1). Kegiatan bersifat insidentil, 2). Penyuluhan hanya bersifat penyampaian materi secara oral, tidak dibarengi dengan praktek, 3). Tidak ada pembinaan lanjut dan monitoring untuk mengetahui tingkat penerapan teori yang telah disampaikan.

Oleh sebab itu dalam upaya memperbesar makna penyuluhan yang sudah dilakukan, ke depan perlu ada tindak lanjut kegiatan, sehingga misi utama untuk memperbesar peran ternak itik sebagai penghasil bahan baku telur asin untuk cindra mata wisatawan dapat tercapai.

\section{KESIMPULAN DAN SARAN}

\section{Kesimpulan}

Dari uraian terdahulu dapat disimpulkan bahwa materi penyuluhan dapat diterima baik oleh peserta, sehingga bermanfaat untuk memperbaiki kinerja produksi ternak itik, dan kelangkaan bahan baku telur asin dapat tertanggulangi. 


\section{Ucapan Terima Kasih}

Ucapan terima kasih dan penghargaan yang setinggi-tingginya disampaikan kepada Universitas Mataram, yang telah memberikan dana untuk pelaksanaan penyuluhan. Ucapan terima kasih dan penghargaan yang setinggi-tingginya juga disampaikan kepada Mahasiswa KKN Universitas Mataram di desa Cendi Manik, serta semua aparat desa Cendi Manik yang telah banyak membantu sehingga kegiatan dapat berjalan sebagaimana mestinya.

\section{DAFTAR PUSTAKA}

Amrullah, I.K, 2002. Nutrisi Ayam Petelur. Lembaga Satu Gunung Budi. Bogor.

Balitbangtan, 2019. Pengawetan Dedak Padi Dengan Cara Fermentasi. BPTP. Sumatra Selatan.

Hesti, 2018. Sebelas Macam Penyakit yang Sering Menyerang Bebek dan Solusinya. Dalam: https://hobiternak.com/11-macam-penyakit-yang-menyerang-bebek-dan-solusinya/

Ketaren, P.P. Dan L.H. Prasetyo. 2000. Produktivitas Itik Silang MA Di Ciawi Dan Cirebon. Prosiding Seminar Nasional Peternakan Dan Veteriner. Pusat Penelitian Peternakan, Badan Penelitian Dan Pengembangan Pertanian, Departemen Pertanian

Ketaren, P.P. 2002. Kebutuhan Gizi Itik Petelur dan Itik Pedaging Wartazoa Vol. 12 No. 2: 37-46

Purnamaningsih, A. 2010. Pengaruh Penambahan Tepung Keong Mas (Pomacea Canaliculata Lamarck) Dalam Ransum Terhadap Kualitas Telur Itik. Skripsi. UIN Alaudin. Makasar.

Setioko, A.R., A.P Sinurat, P. Setiadi, A. Lasmini, P. Ketaren, Dan A. Tanuwidjaja. 1992. Pengaruh Perbaikan Nutrisi Terhadap Produktivitas Itik Gembala Pada Masa Boro. Prosiding Agroindustri Peternakan Di Pedesaan. Balai Penelitian Ternak, Ciawi, Bogor.

Tamzil, M.H. 2017. Ilmu dan Teknologi Pengelolaan Plasma Nutfah Ternak Itik. Penerbit Mataram University Press. Mataram.

Wahyuni, S.H.S. 2003. Fermentasi Dedak Padi Kapang Aspergillus Ficuum dan Pengaruhnya terhadap Kadar Fitat, Kualitas Protein Kasar Serta Energi Metabolis pada Ayam. Jurnal Bionatura. 5 (2): 141 - 149

Wibawa, A.A.P., I W. Wirawan, I. B. Partama. 2015. Peningkatan Nilai Nutrisi Dedak Padi Sebagai Pakan Itik Melalui Biofermentasi Dengan Khamir. Majalah Ilmiah Peternakan. 18 (1): 11-16

WHO., 1959. World Health Organization. Joint WHO/FAO Expert Committee on Zoonoses: Second Report. WHO Technical Report Series. 169: 1-83 